\section{Kidney Blood Pressure Research}

\title{
The Protective Effects of Erythropoietin on Rat Glomerular Podocytes in Culture are Modulated by Extracellular Matrix Proteins
}

\author{
Jan Krtila Jan Pláteník ${ }^{a} \quad$ Nikola Čuř́k ${ }^{c} \quad$ Wunnie Brima ${ }^{a} \quad$ Vladimír Tesařb $^{b}$ \\ Tomáš Zimaa
}

anstitute of Medical Biochemistry and Laboratory Diagnostics; ${ }^{b}$ Department of Nephrology; Institute of Pathological Physiology, First Faculty of Medicine, Charles University in Prague, and General University Hospital, Prague, Czech Republic

\section{Key Words}

Podocyte • Primary culture - Erythropoietin • Extracellular matrix • Attachment factors • Serum deprivation

\begin{abstract}
Background/Aims: Podocytes are typically cultured on collagen I; however, collagen I is absent from healthy glomerular basement membranes. Erythropoietin (EPO) is thought to protect podocytes in vivo. Here, we studied how various types of extracellular matrix (ECM) proteins and EPO affect podocytes in culture. Methods: Primary rat podocytes were replated on collagen I, collagen IV, whole ECM extract, laminin, or bare plastic. Cellular adhesion (8 hours after plating), proliferation (5 days, $10 \%$ serum), and resistance to serum deprivation (3 days, $0.5 \%$ serum) were assessed. BrdU incorporation and expression of podocyte-specific markers were employed as measures of cellular proliferation and differentiation, respectively. qPCR was used to verify expression of EPO receptor in cultured podocytes. Results: Cellular adhesion was similar on all ECM proteins and unaffected by EPO. Proliferation was accelerated by laminin and the ECM extract, but the final cell density was similar on all ECM surfaces. Collagen IV supported the serum-deprived cells better than the other ECM proteins. EPO (2$20 \mathrm{ng} / \mathrm{ml}$ ) improved viability of serum-deprived podocytes on collagen I, collagen IV, and ECM, but not on laminin or bare plastic. The cells expressed mRNA for EPO receptor. Conclusion: The physiological ECM proteins are more supportive of primary podocytic cultures compared with collagen I. The protective effects of EPO during serum deprivation are modulated by the cultivation surface.
\end{abstract}




\section{Kidney Blood Pressure Research}

Kidney Blood Press Res 2013;38:142-155

\begin{tabular}{l|l}
\hline DOI: $10.1159 / 000355762$ & (C) 2014 S. Karger AG, Basel
\end{tabular}

Published onine: IVIarch 15, 2014

www.karger.com/kbr

Podocytic Cultures

\section{Introduction}

Podocytes (glomerular visceral epithelial cells) are highly specialized, terminally differentiated epithelial cells that cover the exterior surface of the glomerular capillary basement membrane with multiple interdigitating, foot-like processes. These cells function as a critical component of the glomerular filtration barrier (GFB) [1]. Podocytes are affected in some glomerulopathies, such as membranous nephropathy, focal segmental glomerulosclerosis, minimal change disease, and diabetic nephropathy [reviewed by 2, 3]. A disease-related reduction in podocyte number and/or density due to apoptosis and/or detachment of living cells leads to the development of proteinuria and glomerulosclerosis [reviewed by 4]. It has been postulated that the glomerular basement membrane (GBM) is also important in establishing and maintaining a properly functioning GFB. The GBM naturally contains type IV collagen, laminin, nidogen, and heparan sulfate proteoglycan; some of these proteins appear in specific isoforms [5]. Podocytes are in contact with the extracellular matrix (ECM) proteins of the GBM via integrins (predominantly $\alpha 3 \beta 1$ integrin), $\alpha$ - and $\beta$-dystroglycans [3].

In vitro cultures have frequently been used to study the (patho)-physiological properties of podocytes. Both primary cultures and immortalized podocytes derived from various species (most frequently human, mouse, or rat) are available. Many groups use conditionally immortalized podocytes in their studies. Although some investigators use type IV collagen [e.g., 6, 7] or laminin [e.g., 8] as an attachment factor, the most commonly used substrate in podocyte cultures is type I collagen [reviewed by 9]. However, as discussed below, the adhesion of podocytes to collagen I in vivo is generally limited to pathological conditions.

Numerous glomerular disorders are associated with altered ECM metabolism in the GBM and mesangium. For instance, in diabetic nephropathy, type IV collagen accumulates and both laminin and heparan sulfate proteoglycan are reduced in the GBM [10]. In Alport syndrome, the lack of GBM-specific type IV collagen together with ectopic laminin deposition contribute to the GBM and podocyte deformations that are associated with this disease [11]. Type I collagen has been identified only in human and experimental glomerulonephritis with advanced glomerulosclerosis. It has been suggested that abnormal synthesis of type I collagen can contribute to progression of glomerulonephritis [reviewed by 12]. He et al. [12] demonstrated that the parietal epithelial cells act as a source of type I collagen, which implies that podocytes can be in direct contact with type I collagen in the diseased glomeruli. In another type of glomerular cells, mesangial cells, alterations in the ECM composition can affect cell behavior, including proliferation, migration and differentiation [reviewed by 13].

As interactions between cells and ECM proteins are crucial for most tissue responses, including cell proliferation, movement, and matrix remodeling [14], it is important to determine whether direct contacts between podocytes and an altered spectrum of ECM proteins affect their behavior in vitro and in vivo. To the best of our knowledge, the complex influence of different ECM components has not yet been studied in primary cultured podocytes, which might be more suitable for proliferation and survival experiments than immortalized or transformed cells $[15,16]$.

Erythropoietin (EPO) was originally described as a hematopoietic growth factor that regulates the proliferation, differentiation, and survival of erythroid progenitor cells. Interestingly, within the last several years, non-hematopoietic protective and therapeutic effects of EPO in tissue culture and animal models of nervous and cardiovascular injuries have also been reported [17]. Furthermore, in the kidney, EPO ameliorates and/or recovers ischemia-reperfusion injury, 5/6 nephrectomy-induced damage, and renal toxicity induced by cis-platin, cyclosporine A [18] or radiocontrast agents [19]. The EPO receptor has been localized to glomerular podocytes in the murine kidney $[20,21]$; it is also expressed by immortalized podocytic cell lines in culture [21-23]. Agonists at the EPO receptor have protective effects on podocytes in various experimental models of renal damage in vivo or in vitro [21-25]. 


\section{Kidney Blood Pressure Research}

Kidney Blood Press Res 2013;38:142-155

\begin{tabular}{l|l}
\hline DOI: $10.1159 / 000355762$ & $\begin{array}{l}\text { C 2 2014 S. Karger AG, Basel } \\
\text { www.karger.com/kbr }\end{array}$ \\
Publisnea onIIne: IVIarch 15, 2014 &
\end{tabular}

Krtil/Pláteník/Čuř́k/Brima/Tesař/Zima: Extracellular Matrix and Erythropoietin in Podocytic Cultures

The ECM is an important mediator of growth factor-regulated events, and many growth factors have been found to interact with the ECM. Although both integrin cell adhesion receptors and growth factor receptors can independently propagate intracellular signals, the synergy of signals from the ECM and growth factors appears to regulate the biochemical responses in multiple cell types during development and/or during pathological processes $[26,27,28]$. Optimal cell stimulation with some growth factors depends on integrinmediated cell adhesion to the appropriate ECM [26]. In the case of glomerular epithelial cells (presumptive podocytes), Cybulsky and colleagues [29, 30,31] reported that ECM proteins modulate cellular responses, including proliferation, to growth factors such as epidermal growth factor (EGF), hepatocyte growth factor (HGF), basic fibroblast growth factor (bFGF), and thrombin.

The aim of our study was to (1) determine which of the commercially available ECM proteins (namely, collagen I, collagen IV, laminin, and a complete ECM protein extract from basement membrane) provides optimal support for the adhesion, proliferation, differentiation, and survival of non-transformed rat podocytes in culture. Moreover, we examined (2) whether EPO affects the behavior of primary cultured podocytes and (3) whether this effect on behavior is modulated by the type of ECM used for cell culture.

\section{Materials and Methods}

\section{Antibodies and reagents}

Mouse anti-BrdU antibody (BU-33), rabbit anti-synaptopodin antibodies (RS-18, SE-19), and mouse anti- $\alpha$-smooth muscle actin antibody (1A4) were obtained from Sigma-Aldrich (St. Louis, MO). The anti-WT-1 (C-19) and anti-CD2AP (H-290) rabbit primary antibodies were manufactured by Santa Cruz Biotechnology (Santa Cruz, CA). The fluorescent-labeled secondary antibodies Alexa Fluor $®$ 488-conjugated anti-rabbit IgG (A11070) and Alexa Fluor® 594-conjugated anti-mouse IgG (A11020), as well as phalloidin conjugated to Alexa Fluor® 488 (A12379), were obtained from Molecular Probes (Life Technologies, Carlsbad, CA).

Recombinant rat erythropoietin (1306-RE, EPO) was purchased from R\&D Systems (Abingdon, UK). Fetal bovine serum (FBS) was provided by PAN Biotech (Aidenbach, Germany). The insulin-transferrinselenium-A supplement (ITS-A) and phosphate-buffered saline (PBS) were obtained from Gibco (Life Technologies, Carlsbad, CA).

The mounting medium, Vectashield $\AA$, containing 4,66 diamidino-2-phenylindole (DAPI) was from Vector Laboratories (Burlingame, CA). The RNAprotect $\AA$ Cell Reagent was provided by Qiagen (Germantown, MD), the mirVana ${ }^{\mathrm{TM}}$ miRNA Isolation Kit was from Life Technologies (Carlsbad, CA), and the iScript ${ }^{\mathrm{TM}}$ cDNA $^{\mathrm{T}}$ Synthesis Kit was from Bio-Rad (Hercules, CA). The UniversalProbeLibrary (UPL) hydrolysis probes were obtained from Roche Diagnostics GmbH (Mannheim, Germany) and were used together with TaqMan Universal Master Mix II (Applied Biosystems, Life Technologies, Carlsbad, CA) in the qPCR analysis. Collagen type I from rat tail (C7661), collagen type IV from human placenta (C5533), laminin from the basement membrane of Engelbreth-Holm-Swarm mouse sarcoma (L2020), ECM protein extract from the basement membrane of Engelbreth-Holm-Swarm murine sarcoma (E1270), RPMI 1640 medium (Dutch modification), penicillin, streptomycin, $0.25 \%$ trypsin with EDTA, 5-bromo-2-deoxyuridine (BrdU), 3-(4,5-dimethyl-2thiazolyl)-2,5-diphenyl-2H-tetrazolium bromide (MTT), and all other reagents were obtained from SigmaAldrich (St. Louis, MO).

\section{Coating of culture plates}

All ECM proteins were used at a final concentration of $100 \mu \mathrm{g} / \mathrm{ml}$. Collagens type I and IV were diluted in $0.02 \mathrm{~mol} / \mathrm{l}$ acetic acid. Laminin was diluted in deionized water, and ECM protein extract was diluted in serum-free RPMI 1640 medium. All types of matrices were applied to 12- or 24-well culture plates at $10 \mu \mathrm{g} /$ $\mathrm{cm}^{2}$ and allowed to attach at $4{ }^{\circ} \mathrm{C}$. After an overnight incubation, excess fluid was removed, the plates were left to air-dry overnight, and then they were sterilized with UV irradiation for $30 \mathrm{~min}$. Before cell plating, the coated wells were washed twice with PBS. In some experiments, bare (uncoated) plastic was also included. 


\section{Kidney Blood Pressure Research}

Kidney Blood Press Res 2013;38:142-155

\begin{tabular}{l|l}
\hline DOI: 10.1159/000355762 & (c) 2014 S. Karger AG, Basel
\end{tabular}

Published onine: IVIarch 15, 2014

www.karger.com/kbr Podocytic Cultures

Primary cultures of rat podocytes

Usage of experimental animals in this study was approved by the Committee for Work with Laboratory Animals at the First Faculty of Medicine, Charles University in Prague. Primary cultures of rat podocytes were prepared as described previously [32], with modification. Briefly, glomeruli were isolated from 8- to 12 -week-old male Wistar rats by differential sieving using sieves with 250,150 , and $75 \mu \mathrm{m}$ pore sizes. The harvested glomeruli were plated on culture flasks coated with rat tail collagen I (prepared according to [33, 34]) and maintained in RPMI 1640 medium supplemented with $10 \%$ FBS, 1\% ITS-A, $100 \mathrm{U} / \mathrm{ml}$ penicillin, and $0.1 \mathrm{mg} / \mathrm{ml}$ streptomycin. Glomeruli were kept at $37^{\circ} \mathrm{C}$ in a humidified, $5 \% \mathrm{CO}_{2}$ atmosphere for 8-9 days. The nearly confluent (subconfluent) outgrowth of the glomerular epithelial cells was trypsinized and separated from the remaining glomerular cores using a $30 \mu \mathrm{m}$ nylon mesh filter. The podocytes were either used for experiments directly after the first subculture, or (in experiments with EPO) cryopreservation of the cells was employed. After thawing, the cells were allowed to recover and grow to confluence, and then they were replated for the experiment (i.e., the $2^{\text {nd }}$ passage was used).

\section{Experimental design}

Cells were generally seeded at a density of $7-8 \times 10^{3} \mathrm{cells} / \mathrm{cm}^{2}$ onto 12 - or 24 -well plates coated with the appropriate ECM protein and cultured for the indicated time in RPMI 1640 with $10 \%$ FBS and $1 \%$ ITS-A (the complete growth medium); later, they were cultured in RPMI 1640 with $0.5 \%$ FBS (the starvation medium), as indicated below.

To assess cell adhesion onto various ECM surfaces, cells in complete growth medium were plated on coated wells and allowed to adhere for 6-7 hours. To remove non-adherent cells, the plates were washed twice with warm PBS; the remaining adherent cells were fixed with $3.7 \%$ formaldehyde in PBS, mounted in Vectashield ${ }^{\circledR}$ with DAPI, and examined with an inverted fluorescence microscope Leica DM IL equipped with a digital camera Leica DC300F (Leica Microsystems GmbH, Wetzlar, Germany). Five digital images of random fields were captured for each culture condition, and the stained nuclei were counted.

To assess cellular growth on various ECM surfaces, cells were seeded onto coated plates in growth medium and allowed to attach overnight; then, the medium was exchanged. After 5 days of culture (when the cells reached confluence), the adherent cells were fixed, stained with DAPI, and counted. Other plates were processed for the MTT test (see below). Additional cells were examined by double labeling for BrdU and WT1 (see below) on culture days 2-3, just before they reached confluence and stopped growing.

In the stress condition experiments, after a 5-day growth period, the complete growth medium was replaced with the starvation medium, and the confluent cells were cultured for an additional 72 hours. The adherent cells were then either fixed and counted or their viability was examined with the MTT test.

In the experiments with EPO, the adhesion assay was performed as described above, except the cells were seeded in the starvation medium with a range of EPO concentrations $(0,2,20,200 \mathrm{ng} / \mathrm{ml})$. Following fixation and DAPI staining, the adherent cells were quantified. After the growth period, the confluent cells were transferred to the starvation medium with different EPO concentrations $(0,2,20,200 \mathrm{ng} / \mathrm{ml})$ and incubated for 72 hours. The cells were fixed and counted, and additional wells were processed for the MTT assay.

MTT assay

Simultaneously to the cell count, metabolic activity of the cells after the growth period and serum deprivation with or without EPO treatment was tested with the MTT assay. The test is based on the fact that living (metabolically active) cells convert a tetrazolium salt into a formazan product, which is measurable by spectrophotometry. The cells were cultured in 12-well plates. In total, $625 \mu \mathrm{l}$ of $0.5 \%(\mathrm{w} / \mathrm{v})$ MTT solution in starvation medium was added to each well. After 4 hours at $37^{\circ} \mathrm{C}, 500 \mu \mathrm{l}$ of extraction buffer $(20 \mathrm{~g}$ sodium dodecyl sulfate dissolved in $100 \mathrm{ml}$ of $50 \%$ (v/v) dimethyl formamide, $\mathrm{pH} 4.7$ ) was added to each well, and the plates were incubated overnight at $37^{\circ} \mathrm{C}$. The amount of extracted formazan was measured as an absorbance at $596 \mathrm{~nm}$ on an HP 8452A diode-array spectrophotometer (Hewlett-Packard Co., Palo Alto, CA). Dishes incubated for the indicated time periods with culture medium, MTT solution and extraction buffer, but without cells, were utilized as blanks. The MTT test data for each experimental condition were obtained from at least 3 independent experiments. 


\section{Kidney Blood Pressure Research}

Kidney Blood Press Res 2013;38:142-155

DOI: $10.1159 / 000355762$

Published onine: Ivarch 15, 2014

(c) 2014 S. Karger AG, Basel

www.karger.com/kbr

Podocytic Cultures

Proliferation assay with double labeling of BrdU and WT-1

To determine how many podocytes have entered S phase of the cell cycle, double labeling of BrdU and WT-1 was used. Briefly, after the overnight seeding and exchange of the growth medium, the cells were cultured for an additional 48 hours. For the last 24 hours of culture, the cells were pulsed with $10 \mu \mathrm{M}$ of BrdU. The cells were fixed in $3.7 \%$ formaldehyde in PBS, and the DNA was denatured with $1 \mathrm{~N} \mathrm{HCl}$ for 15 min at room temperature. After blocking/permeabilization, the cells were incubated simultaneously with rabbit anti-WT-1 (1:20) and mouse anti-BrdU (1:250) primary antibodies either for $2 \mathrm{~h}$ at room temperature or overnight at $4^{\circ} \mathrm{C}$. Next, the antigens were visualized with Alexa Fluor $\AA$ 488-conjugated anti-rabbit IgG and Alexa Fluor® 594-conjugated anti-mouse IgG secondary antibodies, both diluted at 1:200. The cells that were positive for both WT- 1 and BrdU were counted in 5 fields for each experimental condition in at least 3 independent experiments.

Immunofluorescence staining for WT-1, synaptopodin, CD2AP and $\alpha$-smooth muscle actin

Cells were grown on coated 24-well plates. Samples from day 3 of growth were washed twice with PBS and fixed in $3.7 \%$ formaldehyde in PBS for $10 \mathrm{~min}$. The remaining aldehyde groups were blocked with $50 \mathrm{mM} \mathrm{NH}_{4} \mathrm{Cl}$ in PBS for $15 \mathrm{~min}$, followed by quenching of cellular autofluorescence with $1 \%$ sodium borohydride in PBS for 5 min. Next, the cells were subjected to blocking/permeabilization in $10 \%$ normal goat serum and $0.064 \%$ saponin in $1 \%$ BSA in PBS for 60 min. The cells were then incubated with the following primary antibodies diluted in the blocking solution either for $2 \mathrm{~h}$ at room temperature or overnight at $4^{\circ} \mathrm{C}$ : rabbit anti-WT-1 (1:20), rabbit anti-synaptopodin (1:100) rabbit anti-CD2AP (1:20), and mouse anti- $\alpha$-smooth muscle actin (1:200). After they were washed with PBS, the cells were incubated with either Alexa Fluor® 488-conjugated anti-rabbit IgG or Alexa Fluor ${ }^{\circledR}$ 594-conjugated anti-mouse IgG (both 1:200) diluted in the blocking solution for $1 \mathrm{~h}$ at room temperature. After washing, the cells were post-fixed with $3.7 \%$ formaldehyde in PBS, mounted to Vectashield@ with DAPI, and examined with a fluorescence microscope.

\section{F-actin distribution}

Subcellular distribution of F-actin was visualized using phalloidin conjugated to Alexa Fluor® 488. Briefly, after blocking/permeabilization step as above, the cells were incubated with phalloidin diluted in PBS (1:4) for $20 \mathrm{~min}$ at room temperature. The washed and mounted preparations were examined with a fluorescence microscope.

\section{RNA isolation and $q P C R$}

The cultured podocytes were harvested to the RNAprotect® Cell Reagent and stored in the freezer until the qPCR analysis could be performed. Cellular RNA was isolated by the mirVana ${ }^{\mathrm{TM}}$ miRNA Isolation Kit and precipitated by isopropanol. $0.2 \mu \mathrm{g}$ of RNA was used for reverse transcription using the iScript ${ }^{\mathrm{TM}}$ cDNA Synthesis Kit. The actual qPCR was run on ABI 7900HT instrument (Life Technologies, Carlsbad, CA) for 40 cycles $\left(95^{\circ} \mathrm{C}\right.$ for 15 seconds and $60^{\circ} \mathrm{C}$ for 60 seconds) using the UPL hydrolysis probes and couple of designed primers. Every sample was run in pentaplicate. In addition to the EPO receptor gene, the transcripts for Gapdh and Hprt1 were measured as the reference house-keeping genes. Sequences of primers for qPCR (the number of Roche hydrolysis probe used):

Epor (\#40)-F CCACATCCGCTACGAGGT

Epor (\#40)-R GCCTTCCAGGACCTCCAC

Gapdh (\#77)-F ACTTTGTCAAGCTCATTTCCTGCTAT

Gapdh (\#77)-R TTTCTTACTCCTTGGAGGCCATGTAG

Hprt1 (\#95)-F TCCTCCTCAGACCGCTTTT

Hprt1 (\#95)-R CCTGGTTCATCATCATCGCTAATC

The Cq values obtained for the EPO receptor gene were normalized to the mean Cq of the two reference gene amplicons $\left(\Delta \mathrm{Cq}=\mathrm{Cq}_{\text {ref average }-} \mathrm{Cq}_{\mathrm{EPO} \text { receptor }}\right)$ and converted to $\mathrm{RQ}=2^{\Delta \mathrm{Cq}}$.

\section{Statistical analysis}

The data are generally presented as the mean \pm SD; the number of independent experiments (cell preparations) is indicated on each figure and its legend. The InStat software (GraphPad Inc., San Diego, CA) was used for statistical analysis. To evaluate the effects of various ECM surfaces, a one-way analysis of 


\section{Kidney \\ Blood Pressure Research}

Kidney Blood Press Res 2013;38:142-155

\begin{tabular}{l|l}
\hline DOI: $10.1159 / 000355762$ & (C) 2014 S. Karger AG, Basel
\end{tabular}

Publisned oniıne: Iviarch 15, 2014

www.karger.com/kbr

Krtil/Pláteník/Čuř́k/Brima/Tesař/Zima: Extracellular Matrix and Erythropoietin in Podocytic Cultures
Fig. 1. Number of proliferating podocytes 3 days after plating as detected by BrdU and WT-1 double labeling. Data from three cell preparations are shown as the mean \pm SD. * $\mathrm{P}<0.05$ and ${ }^{* *} \mathrm{P}<0.01$ compared to the corresponding collagen I control.

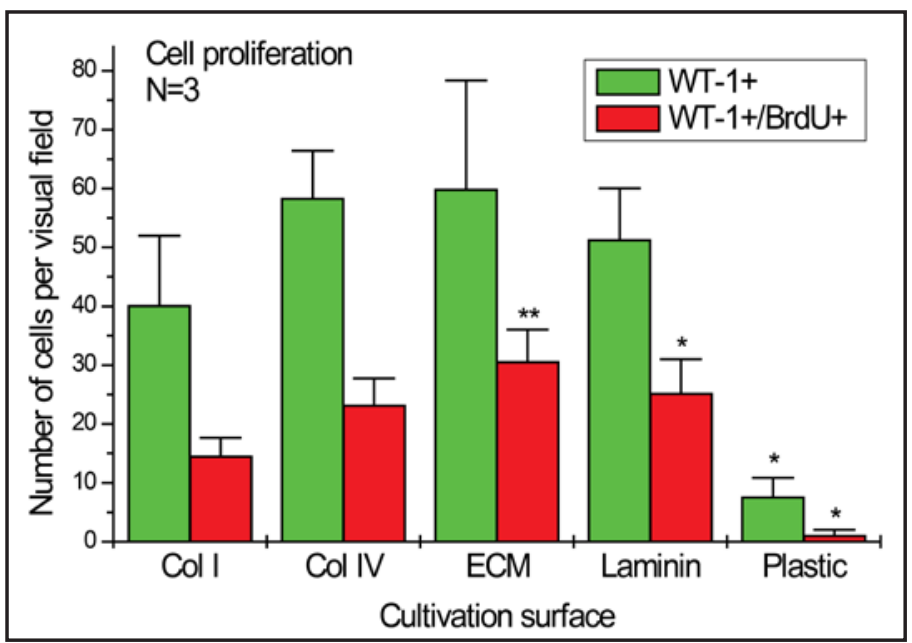

variance (ANOVA) was employed, followed by the Dunnett post-test, in which all groups were compared to the cells growing on collagen I (the control group). For the evaluation of the effects of EPO, repeated-measures ANOVA (with the data from the same cell preparation being paired/matched) was more appropriate. The Dunnett post-test was used to compare all groups to the control group, in this case consisting of cells growing on the same ECM surface but without EPO. The qPCR data were evaluated after scaling (SRQ = RQ/min[all RQs]) and log transformation using ANOVA followed by the Tukey post-test.

\section{Results}

Proliferation of podocytes on various ECM surfaces

Three days after replating, the number of proliferating cells in S phase of the cell cycle was assessed by BrdU incorporation. The number of cells positive for both WT-1 and BrdU (dividing podocytes) was significantly higher on ECM extract and laminin compared to collagen I (Fig. 1). A similar tendency, although one that did not reach statistical significance, was observed for the total number of WT-1 positive cells; in fact, if the fraction of WT-1+/ BrdU+ cells were expressed as \% of all WT-1+ cells, no statistically significant differences among the ECM surfaces were observed. Both the number of WT-1+/BrdU+ cells and the total number of WT-1+ cells also appeared to be slightly increased on collagen IV compared to collagen I, although this increase was not statistically significant (Figure 1).

In contrast, five days after replating, when the cultures generally reached confluence, the resulting cell density (as determined by the number of DAPI stained nuclei) and the cell viability (as determined by the MTT test) were similar regardless of the ECM protein used for coating (Figure $2 \mathrm{~A}, \mathrm{~B}$ ). As expected, the cell growth on bare plastic was poor (Figure 1); the cells tended to form clusters in the well centers and never reached confluence (data not shown).

\section{Differentiation of podocytes on various ECM surfaces}

On the third day after replating the cells started a transition to the arborized phenotype with incipient processes. The proportion of apparently differentiated cells was much higher when assessed five days after replating. As expected, the differentiated state was yet more pronounced after further three days in starvation medium. The expression of several protein markers specific for podocytes was analyzed by immunofluorescence. Cells grown for 3 days in complete growth medium already expressed WT-1, synaptopodin, CD2AP, and $\alpha$-smooth muscle actin; for all of these markers, the intensity and pattern of staining seemed to be the same on all of the ECM surfaces (Fig. 3). Preparations pretreated with $\mathrm{HCl}$ showed WT-1 with a typical nuclear localization. The proportion of WT-1 positive cells was always close to 100 $\%$, indicating the culture was essentially pure. 


\section{Kidney Blood Pressure Research}

Kidney Blood Press Res 2013;38:142-155

\begin{tabular}{l|l}
\hline DOI: $10.1159 / 000355762$ & (c 2014 S. Karger AG, Basel
\end{tabular}

Publisned onilne: TVarcn 15, 2014

www.karger.com/kbr

148

Krtil/Pláteník/Čuřík/Brima/Tesař/Zima: Extracellular Matrix and Erythropoietin in Podocytic Cultures

Fig. 2. Cell density and viability after 5 days of growth on different ECM surfaces. A: Density of cells assessed as the number of DAPI-stained nuclei. B: Viability of cells assessed with the MTT test. Mean \pm SD from 5-7 independent cell preparations. No significant differences were noted.

To analyze the intracellular distribution of F-actin fibers, the cells grown for 3 days on all kinds of ECM were also stained with fluorescent-labeled phalloidin (data not shown). The majority of cells in complete growth medium displayed a subplasmalemmal network of F-actin filaments, which are known to prevail in nondifferentiated podocytes. However, in many cells phalloidin staining revealed already well-developed stress fibers, indicating the ongoing conversion to differentiated phenotype [32]. No qualitative effects of various ECM surfaces on the process of cell differentiation were noted.
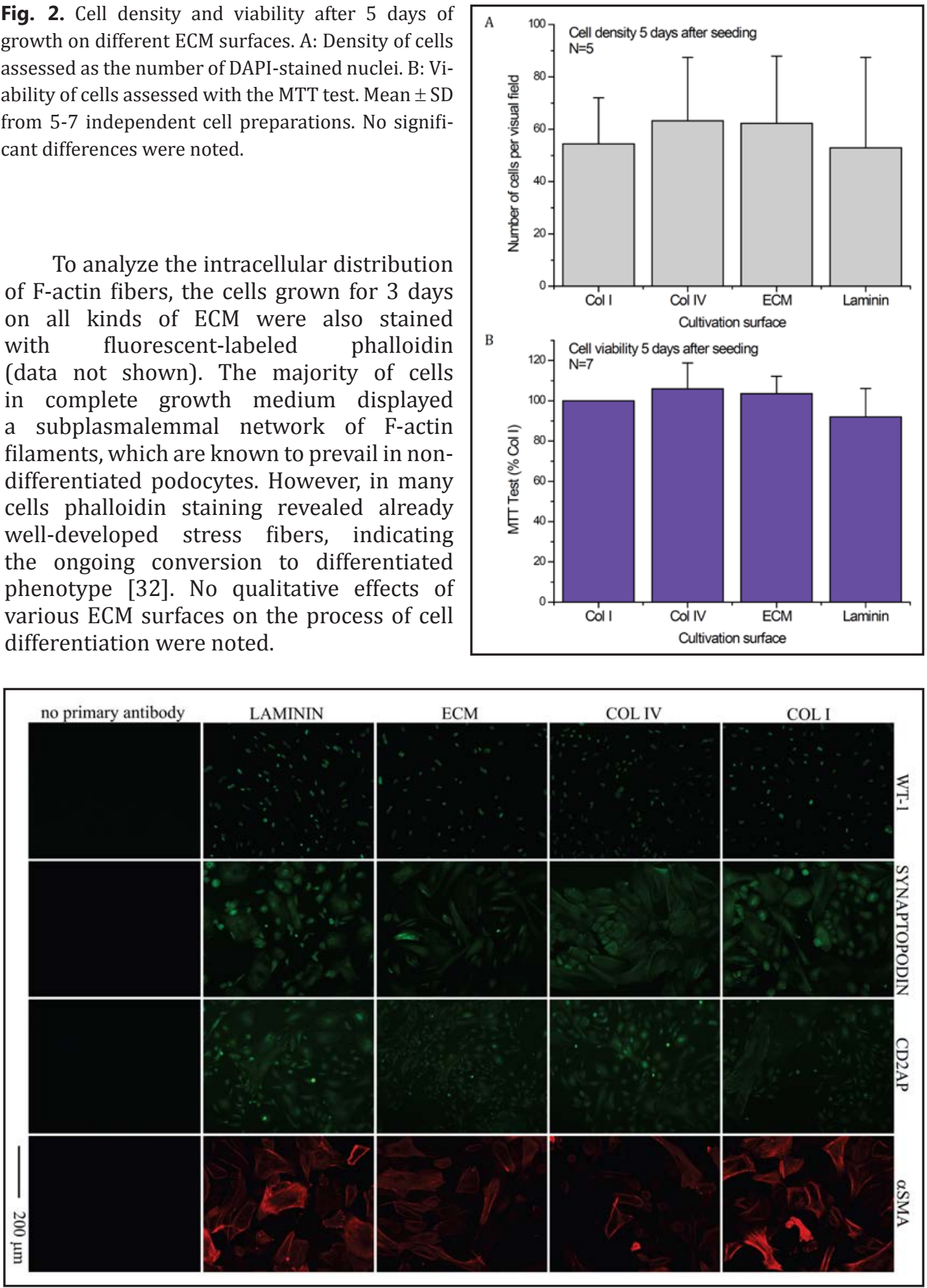

Fig. 3. Expression of podocyte-specific proteins in cells growing on different ECM surfaces. Almost all of the cells expressed podocyte specific proteins regardless of the ECM proteins used for cultivation. On all types of ECM, the WT-1 showed nuclear positivity, synaptopodin showed cytoplasmatic/cytoskeletal localization, CD2AP showed a diffusely cytoplasmatic localization, and $\alpha$-smooth muscle actin displayed a cytoskeletal distribution. The left column of pictures shows negative controls without primary antibodies for each type of staining with cells growing on collagen I. 


\section{Kidney \\ Blood Pressure Research}

Kidney Blood Press Res 2013;38:142-155

\begin{tabular}{l|l}
\hline DOI: $10.1159 / 000355762$ & (c) 2014 S. Karger AG, Basel
\end{tabular}

Publisned oninne: Tvarch 15, 2014

www.karger.com/kbr

149

Fig. 4. Initial cell adhesion on different ECM surfaces. Primary cells were replated directly after the first subculture in full growth medium (10 \% FBS and $1 \%$ ITS-A). The density of adherent cells was assessed as the number of DAPI-stained nuclei 8 hours after seeding. The mean \pm SD was determined from seven independent cell preparations. No significant differences were noted.

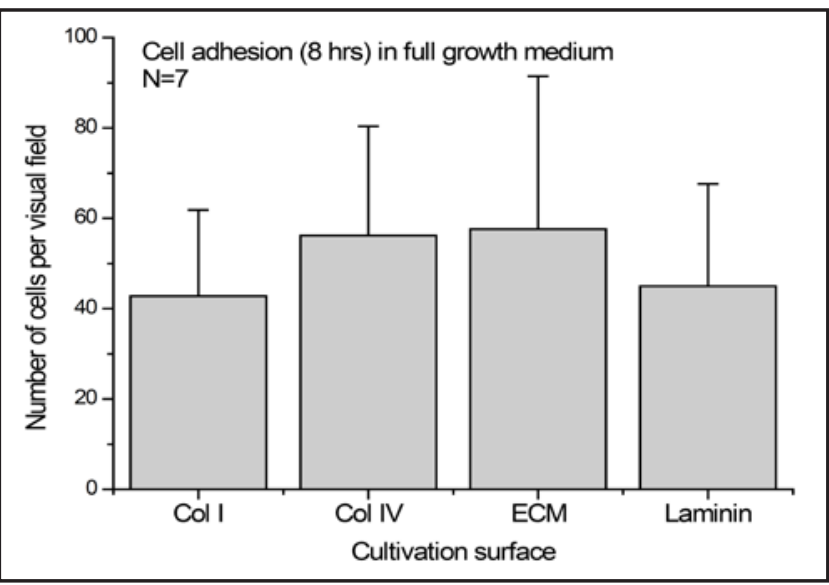

Fig. 5. Effects of EPO on the initial cell adhesion on different ECM surfaces. Cryopreserved cells after thawing were allowed to reach confluence and were then replated on various ECM surfaces in starvation medium (0.5 \% FBS) containing 0-200 $\mathrm{ng} / \mathrm{ml} \mathrm{EPO}$ as indicated. The density of adherent cells 8 hours after seeding was assessed as the number of DAPI-stained nuclei. The mean \pm SD was determined from five independent cell preparations. ${ }^{* *} \mathrm{P}<0.01$ compared to cells plated on collagen I.

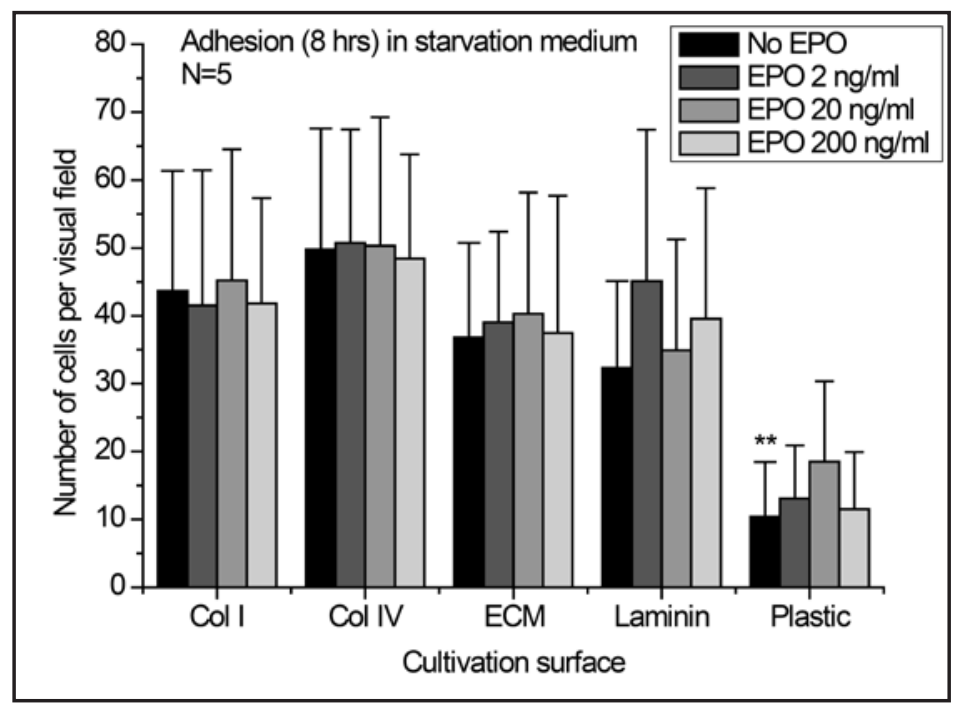

\section{Effects of EPO on cell adhesion to various ECM surfaces}

The initial cell adhesion ( 8 hours in full growth medium) was comparable among all ECM proteins tested (Fig. 4). Likewise, when the cryopreserved cells were seeded in starvation medium, the number of adherent cells was similar among all ECM surfaces, and although there was a tendency towards better adhesion on collagen I and IV compared to ECM extract and laminin, this result was not statistically significant (Fig. 5, columns without EPO). Not surprisingly, significantly fewer cells attached to the uncoated plastic compared to the collagen I surface. No significant effects of EPO could be observed on cell adhesion to any of the cultivation surfaces (Fig. 5).

\section{Effects of EPO on serum-deprived cells on various ECM surfaces}

In additional experiments, the confluent podocytic cultures were challenged with 72 hours of serum deprivation, using starvation medium containing only $0.5 \%$ FBS instead of the usual $10 \%$ FBS. Assessment of the cell density (as determined by the number of DAPI stained nuclei) yielded similar results for all of the ECM proteins (Fig. 6, columns without EPO). However, assessment of cell viability (as determined by the MTT test) revealed that under the stress condition collagen IV could support the cells better than collagen I, whereas no such effect was noted for the ECM extract or laminin (Fig. 7, columns without EPO).

In addition, the starvation condition enabled the observation of modest protective effects of EPO, which appeared to be dependent on the ECM surface. Statistically significant increase in cell viability was observed with $20 \mathrm{ng} / \mathrm{ml}$ of EPO on collagen I, and with both 2 


\section{Kidney Blood Pressure Research}

Fig. 6. Effects of EPO on cell density on different ECM surfaces after three days of serum deprivation. Cells ( $2^{\text {nd }}$ passage) were grown for 5 days on various ECM surfaces, after which the full growth medium was exchanged for starvation medium (0.5\% FBS) containing $0-200 \mathrm{ng} / \mathrm{ml}$ EPO as indicated. After 72 hours of serum deprivation, the density of adherent cells was assessed as the number of DAPI-stained nuclei. The mean \pm SD was determined from five (four for the bare plastic) independent cell preparations. ** $\mathrm{P}<0.01$ compared to cells plated on collagen I. $\S$ $\mathrm{P}<0.05$ compared to cells growing on the same ECM surface but without EPO.
Kidney Blood Press Res 2013;38:142-155

\begin{tabular}{l|l}
\hline DOI: $10.1159 / 000355762$ & $\begin{array}{l}\text { c } 2014 \text { S. Karger AG, Basel } \\
\text { www.karger.com/kbr }\end{array}$ \\
\hline Publisned onlIne: VIVarch 15, 2014 &
\end{tabular}

Krtil/Pláteník/Čuř́k/Brima/Tesař/Zima: Extracellular Matrix and Erythropoietin in Podocytic Cultures

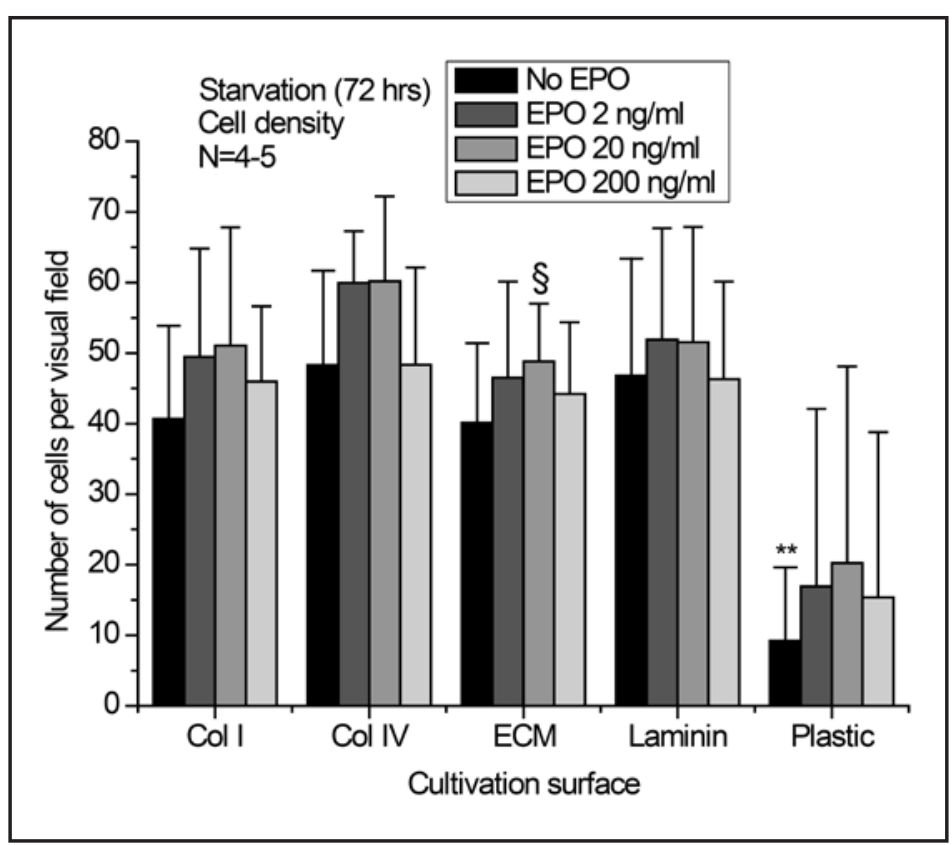

$\mathrm{ng} / \mathrm{ml}$ and $20 \mathrm{ng} / \mathrm{ml}$ of EPO on collagen IV; whereas only $2 \mathrm{ng} / \mathrm{ml}$ of EPO was effective on the ECM extract (Fig. 7). The results of cell density measurement produced similar, although more variable results; a significant effect was noted only for $20 \mathrm{ng} / \mathrm{ml}$ of EPO on the ECM extract (Fig. 6).

When EPO was applied to cells starving on bare plastic, it seemed to increase the cell number as well, although the effect again was not statistically significant due to the high variability between experiments (Fig. 6). However, the cells on the uncoated plastic were not confluent; rather, they thrived only in the well centers. In this situation, the assessment of cell number by taking random snapshots is not appropriate. The MTT test, in which the entire content of each well is processed, is more reliable. This approach convincingly showed that the cell viability is very low on bare plastic and is virtually unaffected by EPO (Fig. 7).

\section{Expression of EPO receptor in cultured podocytes}

The mRNA for the EPO receptor was detected by means of qPCR in podocytes growing on collagen I without EPO at all stages of our experimental arrangement (Fig. 8). The expression of EPO receptor transcript was rather low: 10,000-20,000-times lower than expression of the gene for GAPDH, and 500-1,000-times lower if compared to the level of transcript for HGPRT. Interestingly, in one of the two cell preparations tested, the EPO receptor expression was significantly induced by the serum deprivation in comparison to the proliferation phase (Fig. 8).

\section{Discussion}

In this study, we attempted to grow non-transformed, cultured rat podocytes at the $1^{\text {st }}$ or $2^{\text {nd }}$ passage on several ECM proteins, namely collagen I, collagen IV, laminin, and a complete ECM extract from basement membrane. From our data, it appears that the initial adhesion of cells is similar on all of the ECM proteins. The cells grow well and could reach confluence on all of the ECM surfaces. However, during the proliferation phase, the rate of proliferation was significantly faster on the ECM extract and laminin than on the commonly used type I collagen. The ECM extract should contain mostly laminin and collagen IV; therefore, the 


\section{Kidney Blood Pressure Research}

Kidney Blood Press Res 2013;38:142-155

\begin{tabular}{l|l}
\hline DOI: $10.1159 / 000355762$ & $\begin{array}{l}\text { (c } 2014 \text { S. Karger AG, Basel } \\
\text { www.karger.com/kbr }\end{array}$ \\
Publisned onlIne: vvarch 15, 2014 & .
\end{tabular}

151

Krtil/Pláteník/Čuř́k/Brima/Tesař/Zima: Extracellular Matrix and Erythropoietin in Podocytic Cultures
Fig. 7. Effects of EPO on cell viability on different ECM surfaces after three days of serum deprivation. Cells ( $2^{\text {nd }}$ passage) were grown for 5 days on various ECM surfaces, after which the full growth medium was exchanged for starvation medium (0.5 \% FBS) containing 0-200 ng/ $\mathrm{ml}$ EPO as indicated. After 72 hours of serum deprivation, cell viability was assessed with the MTT test. The data were normalized to the value obtained with the cells growing on collagen I in the absence of EPO for each cell preparation. The mean \pm SD was determined from three independent cell preparations. ${ }^{* *} \mathrm{P}<0.01$ compared to cells plated on collagen I. $\S \mathrm{P}<0.05$; $\S \S \mathrm{P}<0.01$ compared to cells growing on the same ECM surface but without EPO.

Fig. 8. The relative expression of EPO receptor mRNA in cultured podocytes. The cells growing on collagen I were harvested for RNA extraction and qPCR analysis 8 hours after replating, after 3 and 5 days of culture in the full growth medium, and after 3 more days in the starvation medium. Data are shown as the mean \pm SD separately for two independent cell preparations; the error bars represent the methodological error from 3-5 qPCR replicates. * $\mathrm{P}<0.05$.

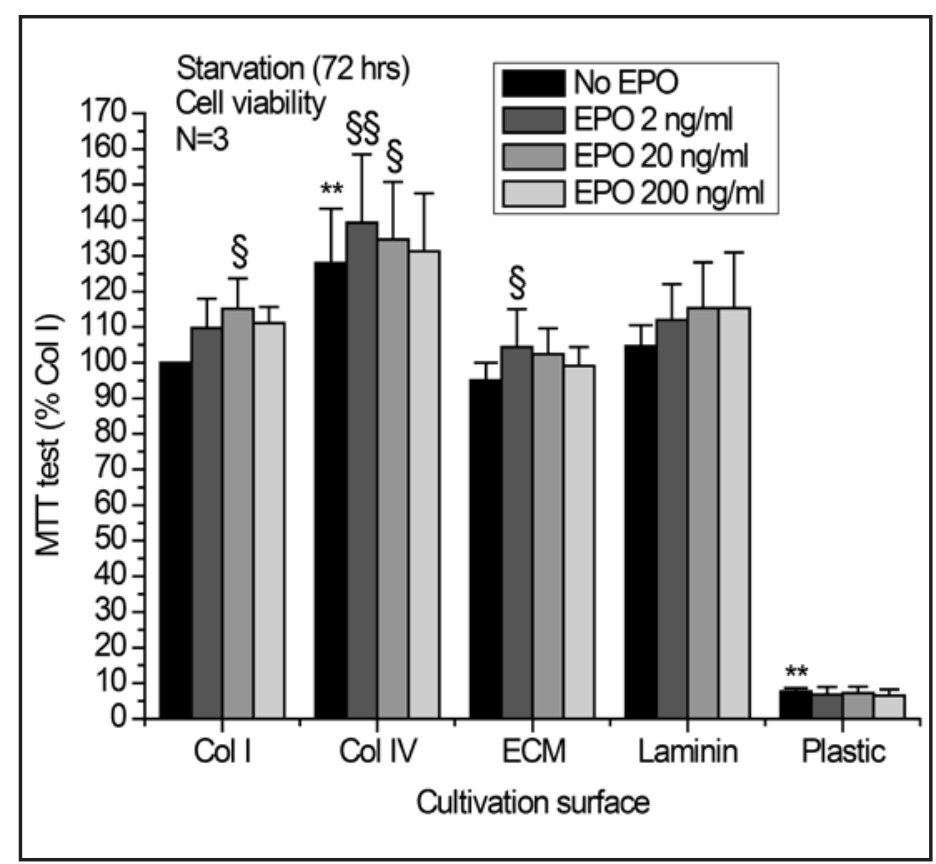

proliferation-promoting agent could be laminin in both cases. However, our data overall suggest that collagen IV contributes to the proliferation rate as well. Already after three days of growth, our cells expressed the common podocyte marker WT-1, as well as synaptopodin and CD2AP, which, together with the overall cell morphology and F-actin distribution indicate that the cells start to differentiate. For all of these markers, both the pattern and intensity of the staining were independent of the ECM surface used for cultivation. When the confluent cells were later challenged with serum deprivation, they were significantly better supported by collagen IV compared to collagen I, while laminin or the whole ECM extract had no effect.

In our experiments, we used primary cultured podocytes, which are thought to be better suited to studies on cell survival and proliferation than immortalized podocyte cell lines [15], and some authors have considered results from studies using transformed, immortalized podocytes to be limiting [16].

There are only a few previous studies that have addressed the effects of various cultivation surfaces on primary podocytes. Mundel et al. [32] compared the influence of collagen I and 


\section{Kidney Blood Pressure Research}

Kidney Blood Press Res 2013;38:142-155

\begin{tabular}{l|l}
\hline DOI: $10.1159 / 000355762$ & (C) 2014 S. Karger AG, Basel
\end{tabular}

Published onine: IVIarch 15, 2014

www.karger.com/kbr

rtil/Pláteník/Čuř́k/Brima/Tesař/Zima: Extracellular Matrix and Erythropoietin in Podocytic Cultures

collagen IV on the growth and differentiation of primary cultured rat and human podocytes. The choice of plating substrate had no qualitative influence on the phenotypic conversion to more differentiated cells. We are not aware of any studies describing the usage of a complex ECM formulation, such as the ECM extract, on the primary podocytes in culture.

Some investigators have studied the influence of some isolated ECM proteins on spontaneously immortalized (transformed) or conditionally immortalized podocytes, as well as fetal renal cortical or adult bone marrow stromal cells that are differentiating into podocytes.

Cybulsky et al. [29] investigated the effects of various extracellular matrices, including collagens I and IV, on both adhesion and proliferation of extensively subcultured (presumably spontaneously immortalized) rat glomerular epithelial cells. No significant difference in cell adhesion was found. Collagen type I in the form of a gel supported cell proliferation most effectively. Thin films of both collagens type I and type IV were also able to support proliferation to a similar extent. In contrast, laminin failed to support cellular proliferation to the same extent. A later study from the same group [35] found that the extensively subcultured primary rat podocytes attached to both collagen I and collagen IV more effectively than to laminin and enhanced cell survival during puromycin-induced damage.

Perry et al [36] compared the influence of collagen I and collagen IV (NC1 hexamers) from intact and diseased (a model of Alport syndrome) canine GBM on murine conditionally immortalized podocytes and bone marrow stromal cells. Regardless of the collagen matrix used, undifferentiated podocytes expressed WT-1 and myosin IIA, while differentiated cells additionally expressed synaptopodin, actin and $\alpha$-actinin. Only CD2AP staining (a marker of differentiated podocytes) was dependent on the type of matrix: on collagen I, only the mature podocytes were positive for CD2AP, whereas on collagen IV (from both intact and diseased glomeruli), CD2AP staining was found in both undifferentiated and differentiated podocytes.

In a very inspiring study, Leapley et al. [37] investigated the behavior of fetal rhesus monkey renal cortical cells throughout five passages cultured on renal ECM (prepared by decellularizing renal cortical cells), collagen I, collagen IV, laminin, and fibronectin. They observed comparable growth rates on all matrices in the early passages; during the later passages, the best proliferation support was provided by the renal ECM. As a marker of differentiation, synaptopodin expression was assessed. At passage 1, very few cells on any substrate showed positive synaptopodin staining. However, during the later passages, the number of cells expressing synaptopodin increased, particularly when grown on fibronectin. Interestingly, bare plastic also allowed an increase of synaptopodin expression, indicating differentiation. Therefore, the authors suggested that fetal renal cortical cells are best supported for proliferation when maintained on renal ECM and for differentiation toward a podocyte lineage when cultured on fibronectin.

Chittiprol et al. [38] performed an extensive investigation of the differences in the behavior of four conditionally immortalized podocytic cell lines, including the effects of various ECM surfaces (collagen I, collagen IV, laminin, fibronectin, the ECM extract, and bare plastic) on cell density. They concluded that the only observable difference among the various cultivation surfaces was a higher cell density in cultures grown on any type of ECM surface compared to bare plastic.

Interestingly, we found that in primary rat podocytes, the differentiation marker synaptopodin appeared earlier than typically reported in conditionally immortalized podocytes (after 10-14 days under non-permissive conditions) [37].

Saleem et al. [39] were the first to demonstrate that differentiated conditionally immortalized podocytes as well as podocytes in vivo express $\alpha$-smooth muscle actin (SMA), which is known as a marker of contractile smooth muscle cells. It is noteworthy that our primary cultured podocytes were also consistently positive for SMA on all ECM surfaces. This protein may thus extend a panel of podocytic markers, demonstrating that the phenotype and function of these cells might be more complex than previously thought. 


\section{Kidney Blood Pressure Research}

Kidney Blood Press Res 2013;38:142-155

\begin{tabular}{l|l}
\hline DOI: $10.1159 / 000355762$ & (C) 2014 S. Karger AG, Basel
\end{tabular}

Published onine: IVIarch 15, 2014

www.karger.com/kbr

Krtil/Pláteník/Čuř́k/Brima/Tesař/Zima: Extracellular Matrix and Erythropoietin in Podocytic Cultures

In the second part of our study, we examined the effects of the growth factor EPO on primary podocytic cultures. Although we assumed that, by analogy with other growth factors $[30,31]$, there can be an overlap between EPO and integrin signaling pathways, no significant effects of EPO on cellular adhesion were noted. Serum deprivation did reveal some subtle but significant protective effects of EPO, which, most interestingly, were dependent on the ECM surface; the protective effects of EPO were observed with collagen I, collagen IV, and the (collagen IV containing) ECM extract but not with laminin or bare plastic. On the ECM extract-coated surface, $20 \mathrm{ng} / \mathrm{ml}$ EPO was needed to increase the number of surviving cells, but only $2 \mathrm{ng} / \mathrm{ml}$ was sufficient to increase cell viability. It seems likely that the lower dose of EPO increases the metabolic activity of cultured cells (as measured by the MTT test), but a higher dose is required to induce measurable pro-survival (antiapoptotic) effects.

Logar et al. [22] studied the effect of darbepoetin $\alpha$ (a long-acting EPO analogue) on conditionally immortalized podocytes cultured on collagen I as well as in an animal model of auto immune glomerulonephritis. The EPO analogue effectively reduced the number of apoptotic podocytes in several models of cell damage in vitro and in vivo, but in vitro, the analogue did not increase cellular proliferation or cell viability as measured by the MTT test. Likewise, Ruester et al. [23] did not find any effect of EPO or EPO analogues on cellular proliferation and viability of undamaged, conditionally immortalized podocytes. EPO, however, effectively protected cells from damage caused by glycated albumin; specifically, EPO reduced cell death and cellular hypertrophy and improved parameters of cell viability and proliferation. Thus, our findings agree with work of others, showing that the protective effects of EPO on podocytes can only be observed if the cells have been damaged. The effects of EPO that we observed may have been relatively subtle because the model of damage serum deprivation - is also relatively mild.

The ECM proteins, namely, collagen I and collagen IV, were shown to facilitate proliferation induced by EGF and other growth factors in cultured podocytes; in fact, the growth factor effects were lost when the cells were grown on bare plastic [30,31]. The collagen-activated integrins inhibit dephosphorylation of the EGF receptor-tyrosine kinase and activate the phospholipase $\mathrm{C} /$ phosphoinositol pathways, which subsequently stimulate or inhibit cellular proliferation, respectively [reviewed by 40]. It is interesting to note that in our experiments, the protective effect of EPO also required cellular attachment to collagen I or IV. Whether a similar cross-talk as observed with EGF exists between EPO signaling, which also involves receptor phosphorylation and the Jak/STAT cascade, and transduction of signals originating at the integrins must be determined in further experiments.

Many other growth factors have been found to interact with ECM components. Growth factor-induced adhesion, proliferation, and migration in cultured cells often depend on specific integrins [26]. One possible mechanism to modify growth factor bioavailability is to immobilize the growth factor in the ECM [28]. In the future, our work may be extended by investigating the possibility of EPO binding to the glomerular ECM.

\section{Conclusion}

Overall, we found that primary podocytes can be cultured on many different types of ECM surfaces, and our results do not challenge the widespread practice of cell culture on collagen I, the most economical protein for cultivation. However, this study demonstrates that with a sufficiently sensitive methodology, differences among cells growing on different surfaces can be revealed. These differences may be important in some studies, and it is important to consider that the physiological attachment protein for podocytes is collagen IV rather than collagen I.

The choice of the ECM protein for cultivation needs to be carefully considered in studies investigating the actions of growth factors. EPO is thought to exert a protective effect on renal podocytes in vivo. The possibility of cross-talk between EPO and signals from the ECM in glomerular podocytes may have implications in glomerular pathologies. For instance, any 


\section{Kidney \\ Blood Pressure Research}

Kidney Blood Press Res 2013;38:142-155

\begin{tabular}{l|l}
\hline DOI: $10.1159 / 000355762$ & C 2014 S. Karger AG, Basel
\end{tabular}

Publisnea onIIne: IVIarch 15, 2014

www.karger.com/kbr

pathological process that changes the composition of the ECM matrix inside the glomerulus may bring about further alteration in the ability of the podocyte to receive vital support from EPO and other local growth factors. This possibility highlights a need for further investigation into the intricate relationship between EPO and ECM signaling.

\section{Conflict of Interests}

The authors of this manuscript state that they have nothing to disclose.

\section{Acknowledgments}

This work was supported by a grant from the Grant Agency of Charles University in Prague, No. 4250/2009, by a research project of Charles University P25/LF1/2, by a grant from Charles University SVV-2012-264512, and by a grant from the Czech Science Foundation P305/11/1745. We thank Richard Buchal for his help with the preparation of the figures for publication.

\section{References}

1 Pavenstädt H: Roles of the podocyte in glomerular function. Am J Physiol Renal Physiol 2000;278:F173-F179.

2 Shankland SJ: The podocyte's response to injury: Role in proteinuria and glomerulosclerosis. Kidney Int 2006;69:2131-2147.

- J Jefferson JA, Alpers CE, Shankland SJ: Podocyte biology for the bedside. Am J Kidney Dis 2011;58:835-845.

4 Ziyadeh FN, Wolf G: Pathogenesis of the podocytopathy and proteinuria in diabetic glomerulopathy. Curr Diabetes Rev 2008;4:39-45.

5 Miner JH: Glomerular basement membrane composition and the filtration barrier. Pediatr Nephrol 2011;26:1413-1417.

6 Endlich N, Sunohara M, Nietfeld W, Wolski EW, Schiwek D, Kränzlin B, Gretz N, Kriz W, Eickoff H, Endlich $\mathrm{K}$ : Analysis of differential gene expression in stretched podocytes: osteopontin enhances adaptation of podocytes to mechanical stress. FASEB J 2002;16:1850-1852.

-7 Schiwek D, Endlich N, Holzman L, Holthöfer H, Kriz W, Endlich K: Stable expression of nephrin and localization to cell-cell contacts in novel murine podocyte cell lines. Kidney Int 2004;66:91-101.

-8 Gao SY, Li CY, Chen J, Pan L, Saito S, Terashita T, Saito K, Miyawaki K, Shigemoto K, Mominoki K, Matsuda $\mathrm{S}$, Kobayashi N: Rho-ROCK signal pathway regulates microtubule-based process formation of cultured podocytes-inhibition of ROCK promoted process elongation. Nephron Exp Nephrol 2004;97:e49-61.

-9 Krtil J, Platenik J, Kazderova M, Tesar V, Zima T: Culture methods of glomerular podocytes. Kidney Blood Press Res 2007;30:162-174.

10 Mason RM, Wahab NA: Extracellular matrix metabolism in diabetic nephropathy. J Am Soc Nephrol 2003;14:1358-1373.

11 Abrahamson DR, Prettyman AC, Robert B, St John PL: Laminin-1 reexpression in Alport mouse glomerular basement membranes. Kidney Int 2003;63:826-834.

12 He JS, Hayashi K, Horikoshi S, Funabiki K, Shirato I, Tomino Y: Identification of cellular origin of type I collagen in glomeruli of rats with crescentic glomerulonephritis induced by anti-glomerular basement membrane antibody. Nephrol Dial Transplant 2001;16:704-711.

13 Sugiyama H, Kashihara N, Maeshima Y, Okamoto K, Kanao K, Sekikawa T, Makiho H: Regulation of survival and death of mesangial cells by extracellular matrix. Kidney Int 1998;54:1188-1196.

14 Suh DY: Understanding angiogenesis and its clinical applications. Ann Clin Lab Sci 2000;30:227-238.

15 Bijian K, Takano T, Papillon J, Le Berre L, Michaud JL, Kennedy CR, Cybulsky AV: Actin cytoskeleton regulates extracellular matrix-dependent survival signals in glomerular epithelial cells. Am J Physiol Renal Physiol 2005;289:F1313-F1323. 


\section{Kidney \\ Blood Pressure Research}

Kidney Blood Press Res 2013;38:142-155

\begin{tabular}{l|l}
\hline DOI: $10.1159 / 000355762$ & C 2014 S. Karger AG, Basel
\end{tabular}

Publisnea onIIne: IVIarch 15, 2014

www.karger.com/kbr Podocytic Cultures

16 Datta K, Li J, Karumanchi SA, Wang E, Rondeau E, Mukhopadhyay D: Regulation of vascular permeability factor/vascular endothelial growth factor (VPF/VEGF-A) expression in podocytes. Kidney Int 2004;66:1471-1478.

17 Li F, Chong ZZ, Maiese K: Erythropoietin on a tightrope: balancing neuronal and vascular protection between intrinsic and extrinsic pathways. Neurosignals 2004;13:265-289.

$\checkmark 18$ Sharples EJ, Yaqoob MM: Erythropoietin in experimental acute renal failure. Nephron Exp Nephrol 2006;104:e83-88.

19 Kolyada AY, Liangos O, Madias NE, Jaber BL: Protective effect of erythropoietin against radiocontrastinduced renal tubular epithelial cell injury. Am J Nephrol 2008;28:203-209.

20 Echigoya MH, Obikane K, Nakashima T, Sasaki S: Glomerular localization of erythropoietin receptor mRNA and protein in neonatal and mature mouse kidney. Nephron Exp Nephrol 2005;100:e21-e29.

21 Eto N, Wada T, Inagi R, Takano H, Shimizu A, Kato H, Kurihara H, Kawachi H, Shankland SJ, Fujita T, Nangaku M: Podocyte protection by darbepoetin: preservation of the cytoskeleton and nephrin expression. Kidney Int 2007;72:455-463.

22 Logar CM, Brinkkoetter PT, Krofft RD, Pippin JW, Shankland SJ: Darbepoetin alfa protects podocytes from apoptosis in vitro and in vivo. Kidney Int 2007;72:489-498.

23 Ruester C, Franke S, Bondeva T, Wolf G: Erythropoietin protects podocytes from damage by advanced glycation end-products. Nephron Exp Nephrol 2011;117:e21-30.

24 Menne J, Park JK, Shushakova N, Mengel M, Meier M, Fliser D: The continuous erythropoietin receptor activator affects different pathways of diabetic renal injury. J Am Soc Nephrol 2007;18:2046-2053.

25 Schiffer M, Park JK, Tossidou I, Bartels J, Shushakova N, Menne J, Fliser D: Erythropoietin prevents diabetesinduced podocyte damage. Kidney Blood Press Res 2008;31:411-415.

-26 Eliceiri BP: Integrin and growth factor receptor crosstalk. Circ Res 2001;89:1104-1110.

$\checkmark 27$ Somanath PR, Ciocea A, Byzova TV: Integrin and growth factor receptor alliance in angiogenesis. Cell Biochem Biophys 2009;53:53-64.

28 Oehrl W, Panayotou G: Modulation of growth factor action by the extracellular matrix. Connect Tissue Res 2008;49:145-148.

29 Cybulsky AV, Bonventre JV, Quigg RJ, Wolfe LS, Salant DJ: Extracellular matrix regulates proliferation and phospholipid turnover in glomerular epithelial cells. Am J Physiol 1990;259:F326-F337.

-30 Cybulsky AV, McTavish AJ, Cyr MD: Extracellular matrix modulates epidermal growth factor receptor activation in rat glomerular epithelial cells. J Clin Invest 1994;94:68-78.

-31 Cybulsky AV, McTavish AJ, Papillon J, Takano T: Role of extracellular matrix and Ras in regulation of glomerular epithelial cell proliferation. Am J Pathol 1999;154:899-908.

-32 Mundel P, Reiser J, Kriz W: Induction of differentiation in cultured rat and human podocytes. J Am Soc Nephrol 1997;8:697-705.

33 Freshney RI (ed): Animal Cell Culture. A Practical Approach. Oxford University Press, Oxford, New York, Tokyo, 1992.

34 Davis JM (ed): Basic Cell Culture. A Practical Approach. Oxford University Press, Oxford, 2002.

-35 Bijian K, Takano T, Papillon J, Khadir A, Cybulsky AV: Extracellular matrix regulates glomerular epithelial cell survival and proliferation. Am J Physiol Renal Physiol 2004;286:255-266.

-36 Perry J, Tam S, Zheng K, Sado Y, Dobson H, Jefferson B, Jacobs R, Thorner PS: Type IV collagen induces podocytic features in bone marrow stromal stem cells in vitro. J Am Soc Nephrol 2006;17:66-76.

-37 Leapley AC, Lee CC, Batchelder CA, Yoder MC, Matsell DG, Tarantal AF: Characterization and culture of fetal rhesus monkey renal cortical cells. Pediatr Res 2009;66:448-454.

-38 Chittiprol S, Chen P, Petrovic-Djergovic D, Eichler T, Ransom RF: Marker expression, behaviors, and responses vary in different lines of conditionally immortalized cultured podocytes. Am J Physiol Renal Physiol 2011;301:F660-F671.

-39 Saleem MA, Zavadil J, Bailly M, McGee K, Witherden IR, Pavenstadt H, Hsu H, Sanday J, Satchell SC, Lennon R, Ni L, Bottinger EP, Mundel P, Mathieson PW: The molecular and functional phenotype of glomerular podocytes reveals key features of contractile smooth muscle cells. Am J Physiol Renal Physiol 2008;295:F959-F970.

40 Cybulsky AV: Extracellular matrix as a determinant of signaling responses in glomerular epithelial cells. Kidney Int 1999;56:1242-1246. 